\title{
Front Matter: Volume 11158
}

, "Front Matter: Volume 11158," Proc. SPIE 11158, Target and Background Signatures V, 1115801 (16 December 2019); doi: 10.1117/12.2555937

SPIE. Event: SPIE Security + Defence, 2019, Strasbourg, France 


\title{
PROCEEDINGS OF SPIE
}

\section{Target and Background Signatures $V$}

\author{
Karin U. Stein \\ Ric Schleijpen \\ Editors
}

9-10 September 2019

Strasbourg, France

Sponsored by

SPIE

Cooperating Organisations

European Optical Society

Cranfield University (United Kingdom)

Published by

SPIE 
The papers in this volume were part of the technical conference cited on the cover and title page. Papers were selected and subject to review by the editors and conference program committee. Some conference presentations may not be available for publication. Additional papers and presentation recordings may be available online in the SPIE Digital Library at SPIEDigitallibrary.org.

The papers reflect the work and thoughts of the authors and are published herein as submitted. The publisher is not responsible for the validity of the information or for any outcomes resulting from reliance thereon.

Please use the following format to cite material from these proceedings:

Author(s), "Title of Paper," in Target and Background Signatures V, edited by Karin U. Stein, Ric Schleijpen, Proceedings of SPIE Vol. 11158 (SPIE, Bellingham, WA, 2019) Seven-digit Article CID Number.

ISSN: 0277-786X

ISSN: 1996-756X (electronic)

ISBN: 9781510630192

ISBN: 9781510630208 (electronic)

Published by

SPIE

P.O. Box 10, Bellingham, Washington 98227-0010 USA

Telephone +1 3606763290 (Pacific Time) · Fax + 13606471445

SPIE.org

Copyright @ 2019, Society of Photo-Optical Instrumentation Engineers.

Copying of material in this book for internal or personal use, or for the internal or personal use of specific clients, beyond the fair use provisions granted by the U.S. Copyright Law is authorized by SPIE subject to payment of copying fees. The Transactional Reporting Service base fee for this volume is $\$ 21.00$ per article (or portion thereof), which should be paid directly to the Copyright Clearance Center (CCC), 222 Rosewood Drive, Danvers, MA 01923. Payment may also be made electronically through CCC Online at copyright.com. Other copying for republication, resale, advertising or promotion, or any form of systematic or multiple reproduction of any material in this book is prohibited except with permission in writing from the publisher. The CCC fee code is 0277$786 \times / 19 / \$ 21.00$.

Printed in the United States of America by Curran Associates, Inc., under license from SPIE.

Publication of record for individual papers is online in the SPIE Digital Library.

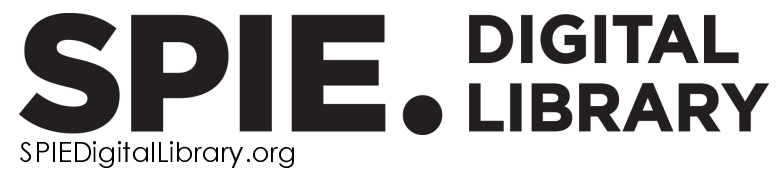

Paper Numbering: Proceedings of SPIE follow an e-First publication model. A unique citation identifier (CID) number is assigned to each article at the time of publication. Utilization of CIDs allows articles to be fully citable as soon as they are published online, and connects the same identifier to all online and print versions of the publication. SPIE uses a seven-digit CID article numbering system structured as follows:

- The first five digits correspond to the SPIE volume number.

- The last two digits indicate publication order within the volume using a Base 36 numbering system employing both numerals and letters. These two-number sets start with $00,01,02,03,04$, 05, 06, 07, 08, 09, OA, OB ... 0Z, followed by 10-1Z, 20-2Z, etc. The CID Number appears on each page of the manuscript. 


\title{
Contents
}

\author{
$\checkmark \quad$ Authors \\ vii Conference Committee
}

SENSOR PROPERTIES AND TARGET DETECTION

1115802 Target detection performance of hyperspectral imagers (Invited Paper) [1 $1158-1$ ]

1115803 A rapid dual-bands infrared detection method for aerial targets based on LCM [1 11 158-2]

UNDERSTANDING SCENES

$1115805 \quad$ Cloud detection and visibility estimation during night time using thermal camera images [1 11 158-5]

1115807 A depth estimation framework based on unsupervised learning and cross-modal translation [1 $11158-7]$

$1115808 \quad$ Visual place recognition based on multilevel descriptors for the visually impaired people [1 11 1 $158-8$ ]

\section{CREATING DATABASES}

$1115809 \quad$ Exploitable synthetic sensor imagery from high-fidelity, physics-based target and background modeling (Invited Paper) [1 $11158-9]$

$111580 \mathrm{~A} \quad$ Semi-synthetic naval scene generation for infrared-guided missile threat analysis with separate setting of apparent temperatures for each target part [1 $1158-10]$

11158 OB Effective 3D modeling method using indirect information of targets for SAR image prediction [1 $11158-11]$

\section{THERMAL BEHAVIOUR}

11158 OC Accurate estimation of temperature distributions for IR signature monitoring with a dynamic thermal model and data assimilation [1 $11158-12]$

11158 OD Infrared signature simulations of a mobile camouflage for a heavy military vehicle [1 $1158-14]$ 
$11158 \mathrm{OE} \quad$ Analysis of target inversion temperature based on infrared dual band [1 $1158-15]$

11158 OF Target infrared characteristic measurement in vacuum chamber [1 $1158-16]$

SURFACE MEASUREMENTS AND MODELLING

$111580 G \quad$ Evaluation of several vegetation indices to detect deep man-made bunkers using field spectroscopy [1 $11158-17]$

$11158 \mathrm{OH} \quad$ Fusion of spectral and directional reflectance information [1 1158-18]

11158 Ol Round robin comparison of BRDF measurements [1 $1158-19]$

11158 OJ The influence of the water on scene IR signature [1 $1158-20]$

11158 OK Modelling sea clutter infrared synthetic images [1 1158-21]

\section{OBSERVER PERFORMANCE}

$11158 \mathrm{OL} \quad$ Determination of the detection threshold of human observers in acoustic drone detection (Invited Paper) [1 $11158-22]$

$111580 \mathrm{M}$ Comparison of land vehicle target detection performance in field observation, photo simulation and video simulation [1 $11158-23]$

$11158 \mathrm{ON} \quad$ Evaluation of target acquisition performance in photosimulation test [1 11 158-24]

POSTER SESSION

11158 OP Research on design distance of visible light camouflage on water target [1 $1158-25]$

$111580 Q \quad$ A new histogram PMHT incorporating pixel noise distribution for dim target tracking [1 $1158-26]$

iv 


\section{Authors}

Numbers in the index correspond to the last two digits of the seven-digit citation identifier (CID) article numbering system used in Proceedings of SPIE. The first five digits reflect the volume number. Base 36 numbering is employed for the last two digits and indicates the order of articles within the volume. Numbers start with 00, 01, 02, 03, 04, 05, 06, 07, 08, 09, OA, OB...0Z, followed by 10-12, 20-2Z, etc.

Bai, Jian, 08

Baker, Christopher J., Ol

Baláž, Teodor, ON

Ballard, Jerrell R., 09

Benoist, K. W., OK

$\mathrm{Bi}$, Yanqiang, $\mathrm{OF}$

Binsbergen, S. A., OK

Bray, Matthew D., 09

Chae, Daeyoung, $\mathrm{OB}$

Chen, $\mathrm{HaO}, 07$

Chen, Lue, 03

Chen, Xin, 03, OE

Chen, Zhongwei, OP

Cheng, Ruiqi, 08

Cropper, A. D., 02

Culpepper, Joanne B., OM

Devecchi, B. A., OK

Fang, Yicheng, 08

Farthing, Matthew W., 09

Fei, Lei, 07

Glendor, Pär, OD

Gong, Zhe, OF

Guo, Qinliang, OF

Gustafsson, Ove, OD

Hallberg, Tomas, Ol

Heutschi, Kurt, OL

Hines, Amanda M., 09

Howington, Stacy E., 09

$\mathrm{Hu}$, Xinxin, 07

Huber, Samuel, OL

Jiang, Shanping, OF

Kala, Nagaraju V., 09

Kariis, Hans, Ol

$\mathrm{Ko}$, Jeong $\mathrm{HO}, \mathrm{OB}$

Krejčí, Jaroslav, ON

Li, Huabing, 07

Li, Peiyin, OF

Liang, Shuo, OF

Livada, Branko, OJ

López Martínez, Marcos, $\mathrm{OH}$

Lu, Fuxing, 03

Mann, David C., 02

Meehan, Alaster, OM

Melillos, George, OG

Messina, Ryan, OM

Moore, Richard P., Ol

Ott, Beat, 05

Park, Ji-Hoon, OB

Pearce, Daniel A., 0 I
Peet, B. J. A., OC

Perić, Dragana, OJ

Portenier, Céline, 05

Racek, František, ON

Rao, Peng, 03, OE

Raven, Peter, 이

Scheers, L. C. W., OK

Scherer-Negenborn, N., OA

Schmied, A., OA

Shang, Yonghong, OF

Shen, Jiafeng, 07

Smith, Milton O., 02

Su, Yueqi, 03

Sun, Chenggang, $\mathrm{OQ}$

Tang, Xingji, OP

Tao, Dongxing, OF

Themistocleous, Kyriacos, $0 G$

Ting, Li, OP

Trautz, Andrew C., 09

van Eijk, A. M. J., OK

Veerman, H. E. T., OK

Wang, Jing, OF

Wang, Kaiwei, 07, 08

Wang, Shuo, $O Q$

Wellig, Peter, 05, OL

Wheaton, Vivienne C., OM

Wunderle, Stefan, 05

Xiang, Kaite, 07

Yang, Kailun, 07, 08

Yin, Lifan, $O Q$

Yoo, Ji Hee, OB

Zhang, HaO, $\mathrm{OE}$

Zhang, Yiqun, $\mathrm{OQ}$

Zhu, Hanlu, OE 
Proc. of SPIE Vol. $111581115801-6$

Downloaded From: https://www.spiedigitallibrary.org/conference-proceedings-of-spie on 26 Apr 2023 Terms of Use: https://www.spiedigitallibrary.org/terms-of-use 


\section{Conference Committee}

Symposium Chairs

Ric Schleijpen, TNO Defence, Security and Safety (Netherlands)

Karin U. Stein, Fraunhofer-Institut für Optronik, Systemtechnik und Bildauswertung (Germany)

Symposium Co-chair

Catherine Barrat, HGH Systèmes Infrarouges (France)

Conference Chairs

Karin U. Stein, Fraunhofer-Institut für Optronik, Systemtechnik und Bildauswertung (Germany)

Ric Schleijpen, TNO Defence, Security and Safety (Netherlands)

Conference Programme Committee

Joanne B. Culpepper, Defence Science and Technology Group (Australia)

Willem H. Gunter, Institute for Maritime Technology (South Africa)

Daniela H. Heinrich, Norwegian Defence Research Establishment (Nonway)

Stacy E. Howington, U.S. Army Engineer Research and Development Center (United States)

Katrin Idla, Tallinn University of Technology (Estonia)

Hans M. Kariis, Swedish Defence Research Agency (Sweden) Luc Labarre, ONERA (France)

Alexander Schwarz, Fraunhofer-Institut für Optronik, Systemtechnik und Bildauswertung (Germany)

Peter Wellig, Armasuisse (Switzerland)

Session Chairs

1 Sensor Properties and Target Detection

Peter Wellig, Armasuisse (Switzerland)

2 Understanding Scenes

Joanne B. Culpepper, Defence Science and Technology Group (Australia) 
3 Creating Databases

Ric Schleijpen, TNO Defence, Security and Safety (Netherlands)

4 Thermal Behaviour

Hans M. Kariis, FOl-Swedish Defence Research Agency (Sweden)

5 Surface Measurements and Modelling

Karin U. Stein, Fraunhofer-Institut für Optronik, Systemtechnik und Bildauswertung IOSB (Germany)

6 Observer Performance

Stacy E. Howington, U.S. Army Engineer Research and Development Center (United States) 